\title{
Cash Flow Problems Can Kill Profitable Companies
}

\author{
Derrald Stice ${ }^{1}$, Earl K. Stice ${ }^{2} \&$ James D. Stice ${ }^{3}$ \\ ${ }^{1}$ Department of Accounting, School of Business and Management, Hong Kong University of Science and \\ Technology, Hong Kong \\ ${ }^{2}$ PricewaterhouseCoopers Professor of Accounting, Marriott School of Business, Brigham Young University, Provo, \\ Utah, USA \\ ${ }^{3}$ W. Steve Albrecht Professor of Accounting, Marriott School of Business, Brigham Young University, Provo, Utah, \\ USA
}

Correspondence: Derrald Stice, Department of Accounting, School of Business and Management, Hong Kong University of Science and Technology, Clear Water Bay, Kowloon, Hong Kong. Tel: 852-2358-7556.

Received: September 9, 2017

Accepted: September 18, 2017

Online Published: September 22, 2017

doi:10.5430/ijba.v8n6p46

URL: https://doi.org/10.5430/ijba.v8n6p46

\begin{abstract}
Although the cash flow statement has been required in public financial reports since 1988 in the United States (and since 1994 according to International Financial Reporting Standards), these important cash flow data are still often overlooked in standard financial analyses. Accounting net income measures economic performance which does not necessarily match up with the timing of cash flow. Many profitable businesses have been killed by cash flow problems, often in the start-up phase. A business has three types of cash flows: operating, investing, and financing. A key measure of cash flow health is free cash flow, the amount of operating cash flow generated in excess of the cash needed for important spending such as for capital expenditures. Managers must pay particular attention to the difference in timing between when cash is collected from customers from the sale of inventory and when cash must be paid to suppliers for the purchase of that inventory. A significant discrepancy between those numbers indicates a potential cash flow problem. Managers and owners of a business that is burning through cash spend much of their time worrying about cash flow survival and are therefore distracted from making the tactical and strategic decisions important to the long-run success of their business.
\end{abstract}

Keywords: operating cash flow, start-up companies, free cash flow, accrual accounting

The international news during 2015 was dominated by Greece and its national debt. For years, Greece has been involved in acrimonious negotiations with the European Union and the International Monetary Fund regarding ongoing debt payments and debt restructuring. The total national of debt of Greece is about $\$ 400$ billion (CIA 2013). However, it isn't the size of the debt that is the source of the problem; the national debt of the United States is much larger, at $\$ 12,400$ billion. And the problem isn't even the size of the debt relative to the economy; the national debt of Greece is $170 \%$ of the country's annual gross domestic product (GDP), but the national debt of Japan is even larger, at $230 \%$ of GDP. The reason that Greece is often in the financial news is that the country does not have the cash flow to make the payments currently due on its loans. Both the United States and Japan have much larger debt loads, but because those countries have sufficient cash flow to make their loan payments on time, no one spends any time talking about debt restructuring or national bankruptcy for Japan or the United States. The problem of Greece is not the size of the national debt; instead, the problem is a lack of cash flow.

Similarly, many good businesses have died a premature death because they didn't properly manage their cash flow. Loans are repaid with cash. Employees are paid with cash. Suppliers are paid with cash. Taxes are paid with cash. A company can't live very long when it doesn't properly manage its cash flow to be able to repay it loans, pay its employees, pay its suppliers, and pay its taxes.

Even profitable companies can experience cash flow problems. Net income, or profit, is a measure of economic value added. The timing of operating cash flow is not necessarily the same as the timing of economic performance. For example, on November 17, 2013, Boeing announced that it had received an $\$ 11.4$ billion aircraft order from flydubai, a low-cost airline owned by the emirate of Dubai (Boeing 2013). This certainly was good news for Boeing (Boeing's opening share price increased 3.06\% the day after this announcement), but Boeing had not yet delivered 
any added value to flydubai as of the date of the announcement. In fact, under this contract, Boeing is scheduled to deliver the first aircraft to flydubai no sooner than 2017. Additionally, the cash flow from flydubai to Boeing is not precisely connected to this delivery schedule; the timing of that cash flow is negotiated separately. During the period of the contract, Boeing's financial department not only needs to monitor the satisfaction of its performance obligation (in order to measure the economic value-added to be reported as revenue in the income statement) but also needs to forecast and track its cash flows (to make sure it can pay its employees, suppliers, and banks on time).

The cash flow statement has been required in public financial reports since 1988 in the United States (FASB 1987) and since 1994 according to International Financial Reporting Standards (IASB 1992). However, these important cash flow data are still often overlooked in standard financial analyses. Standard financial ratio analysis tools, such as the DuPont Framework, are based solely on balance sheet and income statement numbers. In this paper we emphasize that the cash flow data are essential to understanding a company's financial viability, especially for start-up companies.

\section{The Home Depot Story}

We have been teaching business school cases for years. Our favorite case involves the 1985 cash flow problems of a U.S. company named Home Depot (Palepu 1988). Home Depot is a home repair "do it yourself" retailer. As we tell our students when we teach this case, in 1985 Home Depot's "cash burn rate" had placed the company just three weeks from death because of cash flow problems.

In the 2016 Fortune 500 listing of the largest companies in the United States, Home Depot is Number 28 (Fortune 2016). Home Depot is by far the dominant home improvement retailer in the United States and in the world. Most people don't know that Home Depot was close to death back in 1985. An analysis of Home Depot's financial statement numbers from 1985 reveals that the company's net income was down, but the income drop didn't indicate an immediate crisis. There was no crisis, unless you looked at the cash flow numbers. During 1985, Home Depot's operations were burning through $\$ 4$ million per month. That is, the amount of cash paid to suppliers, to employees, and for other operating expenses was $\$ 4$ million larger than the amount of cash collected from customers. $\$ 4$ million per month!

And there was additional bad cash flow news. During 1985, Home Depot also burned through an average of $\$ 8$ million per month building new stores and buying some stores from other companies. In total, Home Depot's 1985 "cash burn rate" was $\$ 12$ million per month ... \$8 million burned through capital spending and $\$ 4$ million burned through daily operations.

Start-up companies often keep track of their "cash burn rate." A start-up company starts off with a pile of cash ... cash from the personal savings of the founders (usually not very much), cash from early investors, and maybe some cash from a local bank loan. The goal of the start-up company is to start generating cash from profitable business operations before burning through all of that initial pile of cash. The size of that initial pile of cash, combined with the "cash burn rate," gives the company founders an idea of how long they can last before they have to go back out into the streets looking for additional financing.

In Home Depot's case, back in 1985, remember that the company was burning through cash at the rate of $\$ 12$ million per month. In 1985, the company had borrowed $\$ 92$ million. That was in addition to the $\$ 120$ million the company had borrowed the year before. Could Home Depot just keeping borrowing cash forever? This is exactly the situation that the country of Greece found itself in during the summer of 2015.

Well, when 1986 started Home Depot had a cash balance of $\$ 9$ million. With a "cash burn rate" of $\$ 12$ million per month, that left them just three weeks of remaining cash. Three weeks to come up with a cash flow plan. Three weeks, with the cash burning away at $\$ 3$ million per week. Three weeks to arrange new loans or get additional cash from investors. Or three weeks to come up with a plan to slow down, or even reverse, this "cash burn rate."

So, what did they do? We're not going to tell you yet. We need some background in cash flow analysis first before we are ready to appreciate the beauty of what the managers of Home Depot did back in 1985 to save the company. Keep reading.

\section{Cash Flow Issues Associated with Starting a Business}

The uncomfortable truth is that cash flow problems can KILL companies, even when those companies have a profitable business model. How do cash flow problems arise, and how can they kill a company? To address these two questions, let's assume that we are starting a building supply business, similar to Home Depot, but we will sell to contractors and home builders, not to general retail customers. And we'll focus on opening just one store. 
As we think through this process of opening our one store, let's focus on CASH. In particular, notice how long we have to SPEND cash until we finally start to COLLECT cash.

\section{Step 1 -- Coming Up with the Business Idea}

The good news here is that often this step doesn't require our spending any cash. We think, we talk with friends, and we look around at existing businesses. Of course, we can hire some business advisors to help in this "idea generation" process, but for this example let's assume that all of this work is in our heads, so it doesn't cost any cash.

\section{Step 2 -- Get the Land, Building, and Key Personnel}

In this example, we are assuming that our business idea is to run a building supply wholesale business, selling many of the same things sold by Home Depot but selling them to high-volume customers such as contractors and home builders.

Well, we need land upon which to build our store, and we need the store itself. We are now up against our first cash flow problem. How do we get the land and the building?
-
We can invest our own cash to buy the land and the building.
OR, we can dilute our company ownership by bringing on a partner or some shareholders who can contribute cash.
- OR, we can borrow the cash from a bank by signing a mortgage agreement. Even then, the bank will insist that we put up some of our own cash as a down payment.

- OR, we can lease/rent the land and building from a real-estate company. They will insist that we make an initial cash payment and that we start making regular monthly payments.

If we can't make any of these arrangements, then our business is already dead because we don't have sufficient cash to get our land and building.

And we also need to start hiring our management team. These key people will probably insist on being paid in cash. OR they might agree to work in exchange for receiving an ownership share of the company. So, we might have to give up some of our ownership to solve the problem of lack of cash to pay these key people in our management team.

\section{Step 3 - Buy Inventory}

We can't open an empty store; we have to fill it with inventory. Our suppliers may allow us to buy the inventory on credit. But we can't wait forever to pay. Our suppliers will insist that we pay in 30 days or, at the most, 60 days. Because we are a new company, during this start-up phase it is reasonable to expect that our suppliers will make us pay in 30 days or less. They want to make sure that they get their cash; after all, they have cash flow concerns as well.

So, we buy that first batch of inventory, on credit, and the clock starts ticking. We are sitting on a cash flow time bomb. Before those 30 days elapse, we have to get the cash to pay our suppliers.

\section{Step 4 -- Start Paying Our Normal Operating Expenses}

Now we need to hire, and start paying, our regular staff: the people at the inventory receiving dock, the cashiers, the aisle sales assistants, and the security guards. We need to start paying for advertising. We need to pay for electricity and insurance. Now we are paying out LOTS of cash to lots of different people. And we still haven't collected any cash from our customers. Our business could die right here from lack of cash.

\section{Step 5 -- Customers Come ... Finally!}

We open the doors, and those beautiful customers start coming in and buying our inventory. Here is the payoff... but not so fast. Our customers - home builders and contractors - are business people and are used to buying on credit. And because we are just getting started and want to be attractive to our new customers, we are going to sell to them on credit. In fact, at least in this initial phase, we might offer generous credit terms (such as payment in 60 days) to get customers to give us a try.

We just made our cash flow problems worse. Customers are taking inventory off our shelves and are promising to pay us in 60 days. We have to replace that inventory by buying more from our suppliers. And they are making us pay in 30 days. We are going to have to pay for the initial stock of inventory AND pay for the replacement inventory BEFORE we collect any cash from our own customers. Once again, right here we could die a cash flow death. And in a cruel twist, the more successful we are, the worse our cash flow problems will be as our customers buy lots of inventory which we have to replace and pay for before our customers ever pay us. 


\section{Step 6 -- Finally, We Start Collecting Some Cash}

After 60 days elapse, those first customers start paying us the cash they owe us. In the meantime, we have been paying our rent, paying our employees, and paying our suppliers. So, our customers will pay us ... IF we are still around. IF our early cash flow problems haven't killed us already. And notice that it really doesn't matter what kind of profit margin we are making on the sale of our inventory. If we don't manage our cash flow, we, and our beautiful profit margin, will die together. A cash flow death.

You may be saying to yourself: “The business I am starting doesn't involve physical inventory; I am safe because I am selling a service." You are correct in thinking that paying for inventory is not a cash flow worry for you. But you still have to pay for employees, utilities, rent, and other operating expenses before your credit customers start paying you in cash. All start-up companies, both those selling goods and those selling services, have potential cash flow problems.

\section{Cash Flow Categories: Operating, Investing, and Financing}

The statement of cash flows is the most recent of the primary financial statements. The balance sheet and the income statement have been around for over 500 years. In contrast, the statement of cash flows first started appearing in just 1988, so to accountants it still feels like it is brand new. For this reason, many managers, trained by tradition-bound instructors, still focus on the balance sheet and the income statement and just skip past cash flow data.

The idea behind the statement of cash flows is very simple: How much cash did you collect and how much cash did you pay? The important reporting decision made when the statement of cash flows was invented was to separate these cash flows into three categories: operating activities, investing activities, and financing activities. (Note 1)

Operating activities are the things that you do every single day; your operations. You collect cash from your customers and hopefully lots of it. You pay wages, you pay utilities, you pay your taxes, and you pay your interest. Those are all things that you do every single day. Operating activities are the routine stuff that you do hundreds of times a day.

In the context of the statement of cash flows, when we say "investing activities" we primarily mean investing in the productive capacity of the business. So, cash outflows from investing activities are buying new buildings, buying new land, and buying new equipment ... spending cash to enhance the productive capacity of the business. Cash inflows from investing activities come from selling a truck or some land when you don't need them anymore.

How often does a company engage in investing activities? Occasionally, but not every day. These are not routine things. A business owner doesn't go out and buy a building for her business every single day. Investing activities -investing in the productive capacity of the business -- happen occasionally; operating activities happen every day.

Financing activities are just what they sound like: the business owner is getting the cash to buy what she needs in her business. She is borrowing some money. She is getting new investment from owners. Those are cash inflows from financing activities. Cash outflows? Well, the business owner is repaying those loans. She is paying dividends to her fellow shareholders or partners. Those are cash outflows from financing activities. How often does a business owner do financing activities? Only occasionally; not very often.

Operating activities are those things that I do every single day, repetitively, over and over. Conducting operating activities is the reason my business exists. Investing and financing activities happen occasionally.

Those three cash flow categories provide the structure of the statement of cash flows. The cash flow statement has been around for only 28 years, but it's been 28 awesome years.

We like sport statistics and records, so let's talk about the operating cash flow world's record. Until 2015, Exxon Mobil held the world's record for the most operating cash flow generated in one year, with $\$ 59.725$ billion generated in 2008 (Exxon Mobil 2009). You probably recall that 2008 was the worst economic year, worldwide, since the Great Depression. Stock prices were down around the world by 30 to 40 percent. So, how was anyone setting an operating cash flow record in that kind of economic environment? Well, 2008 was also the year that oil prices reached their highest level ever. In fact, as long as we are talking about records, the record for oil prices, $\$ 147$ per barrel, was set on July 11, 2008. It was in that environment that Exxon Mobil set the operating cash flow world's record.

In 2014, there was some excitement among those of us (strange) people who pay attention to this kind of thing, cash

flow records. Apple was getting close to the record! Strong operating cash flow performance suggested that, with a good fourth quarter, Apple could break Exxon Mobil's record. In the end, Apple was SO close. For its 2014 
reporting year, Apple had operating cash flow of $\$ 59.713$ billion. just $\$ 12$ Million short of Exxon Mobil's record (Apple 2014).

Well, the cash flow record watch was on again in 2015. Through the first half of the year, Apple's operating cash flows totaled almost $\$ 53$ billion, easily on track to beating Exxon Mobil's 2008 annual record. And the strong cash flow performance continued in the second half of the year; for its 2015 reporting year, Apple's operating cash flow was $\$ 83.266$ billion, shattering Exxon Mobil's 2008 record (Apple 2015). An interesting topic, to discuss another time, is how successful companies, such as Apple, attempt to manage the problems associated with a large surplus of cash flow.

\section{Managing Operating Cash Flows}

For a company that sells a product, the company's operating cycle is the amount of time that elapses from when the company buys its inventory until when the company collects the cash from selling that inventory. The length of the operating cycle is the sum of the length of two very different processes:

- How long from when a company buys its inventory until it sells or uses that inventory?

How long from when a company makes a sale until the company collects the cash from that sale?

Let's talk about that first length of time which is often called the "number of days' sales in inventory." Let us illustrate with an example. Nike makes athletic shoes and other sportswear. Nike manufactures these items and then sells them to retail outlets, typically on credit. In terms of the length of Nike's operating cycle, we must first consider how many days elapse from the time that Nike buys raw materials until the time that Nike sells the finished shoes and sportswear. Using data from Nike's financial reports, it can be computed that this is about 91 days. This is called the "number of days' sales in inventory" (Nike 2015) That is, Nike buys raw materials, and 91 days, on average, elapse before that inventory is turned into finished product and shipped to the retail stores that sell shoes and sportswear.

We then must determine how long until Nike collects the cash from these sales to retail outlets. On average, this is about 41 days. We call that the "average collection period." If you take those two numbers together --- 91 days from the purchase of the raw materials to the sale of the finished shoes and sportswear and 41 days from the sale to the cash collection --- you get 132 days which is the length of Nike's operating cycle.

When Nike purchases its raw materials on credit from its suppliers, Nike pays in about 44 days. So, Nike buys raw materials on credit and then pays for those raw materials after about 44 days. But Nike doesn't collect the cash from selling the finished shoes and sportswear until a total of 132 days have elapsed. This is why companies such as Nike must carefully manage purchases, sales, and cash collections in order to balance out this mismatch between the timing of cash payments and cash collections.

If Nike wishes to manage its operating cash flow, the company has three "dials" it can turn.

Number of days' sales in inventory. In a manufacturing company, such as Nike, reducing the number of days' sales in inventory involves streamlining the production process to get materials through the process as quickly as possible. The longer it takes to make the shoes, after buying the materials, then the longer Nike has to wait until collecting the cash from the sale of the shoes. In addition, Nike has to carefully plan its production so that completed products don't sit around in finished goods inventory for long periods of time waiting for retailers to buy them. On the flip side, Nike must be careful not to rush the production of its inventory, creating a potential quality control issue. The company must manage its inventory according to the "Goldilocks" principle - not too much inventory, not too little inventory, but just the right amount of inventory.

Average collection period. If Nike allows its customers (the retail stores) to delay paying for their purchases, that means that Nike must borrow cash in order to pay its own bills while waiting for the customer cash. There is a fine balance here: balancing the desire to collect the cash with the desire to please the customer by not pestering for cash payment too quickly.

Number of days' purchases in accounts payable. Managing operating cash flow sometimes means stretching out the time when you pay your suppliers. Again, this is a balancing act. If you can stretch out this time, which averages 44 days for Nike, then you are preserving your cash to pay for other things. However, you don't want to anger your suppliers by keeping them waiting too long.

If we put all the numbers together, it takes Nike 132 days to convert purchased raw material into operating cash collections --- 91 days to make and sell the product and 41 days to collect the cash. In the meantime, Nike PAYS for 
those raw materials in about 44 days. So, for 88 days (the difference between 132 days and 44 days), Nike has to use cash from other sources to keep its operation going.

Of course, in a steady state, Nike, and other companies, can use cash collected from prior sales to pay for the materials purchased to make goods for future sales. But in a growing business, where cash payments to make goods for future sales are greater than cash collected from past sales, this operating cycle mismatch can create large operating cash flow shortfalls.

To see a different operating cash flow pattern, let's talk about the cash operating cycle at McDonalds. We love the cash flow pattern of McDonalds. From the time that McDonalds buys raw materials (food and packaging) until McDonalds sells the finished product (the food wrapped in the packaging), about seven days elapse (McDonalds 2016). (Note 2) Cash collection takes about two seconds because even when the customer uses a credit or debit card, McDonalds gets its electronic cash almost instantly. So, the length of the McDonalds operating cycle is seven days plus two seconds ... seven days from the purchase of the raw materials until the sale and then two more seconds to collect the cash.

McDonalds pays its suppliers in 58 days. So, for at least 51 days (58 days minus seven days and two seconds), McDonalds has the cash before needing to use it to pay its own suppliers. This means that, with this pattern of operating cash flows, McDonalds, or another company with a similar operating pattern, could grow as fast as it wanted, with the operating cycle itself providing all of the cash to finance the operating growth.

\section{General Motors: Death and Rebirth as Seen in the Cash Flows}

We can learn a lot about the ups and downs of General Motors over the past 15 years by looking at the company's free cash flow. There are many ways to define "free cash flow," but a basic definition is as follows:

\section{Operating Cash Flow minus Capital Expenditures}

Here are General Motors' free cash flow numbers for the years 1998 through 2001 (General Motors 1998-2014). (Note 3)

\begin{tabular}{|l|r|r|r|r|}
\hline \multicolumn{5}{|c|}{ The Glory Days and the Beginning of the Slide: 1998-2001 } \\
\hline (millions of U.S. dollars) & 2001 & 2000 & 1999 & 1998 \\
\hline Operating cash flow & $\$ 9,166$ & $\$ 19,750$ & $\$ 27,030$ & $\$ 14,343$ \\
\hline Capital expenditures & $(8,631)$ & $(9,722)$ & $(7,384)$ & $(8,231)$ \\
\hline Free cash flow & $\$ 535$ & $\$ 10,028$ & $\$ 19,646$ & $\$ 6,112$ \\
\hline \hline
\end{tabular}

Let's consider a couple of questions. First, we see that FREE CASH FLOW in 1999 was $\$ 19.646$ billion. What could General Motors do with this free cash flow? Anything!!

- Repay loans

- Pay cash dividends

- Repurchase its own shares

- Make higher future capital expenditures

If we had been standing in early 2000 looking into the future of General Motors, we would have seen a company with HUGE possibilities. A company with $\$ 20$ billion in free cash flow can do anything.

Consider another question: In order to maintain its cash dividend payments in 2001, what did General Motors probably have to do? With substantially lower free cash flow, General Motors almost certainly had to BORROW in 2001 in order to maintain its cash dividend payments. In fact, in 1999 General Motors paid \$1.367 billion in dividends. With net income of $\$ 6$ billion, we would have predicted something like this, maybe a little higher. Where did the company get the cash to pay these dividends? No problem... from free cash flow. To maintain these dividends in 2001, General Motors would have had to borrow money. In just two short years the cash flow data show General Motors going from being a company with unlimited possibilities to a company that is borrowing money to pay its dividends. This is a terrible development. 
What happened during these two years? Well, that would be an interesting thing to investigate, certainly beyond the scope of this article. But what we can see is that the whole nasty business is summarized quite nicely in a few cash flow numbers.

Now, let's look at some General Motors free cash flow numbers from a few years later.

\begin{tabular}{|l|r|r|r|r|}
\hline The Death March: $2005-2008$ & & & \\
\hline (millions of U.S. dollars) & 2008 & 2007 & 2006 & 2005 \\
\hline Operating cash flow & $(\$ 12,065)$ & $\$ 7,731$ & $(\$ 11,759)$ & $(\$ 16,856)$ \\
\hline Capital expenditures & $(7,530)$ & $(7,542)$ & $(7,902)$ & $(8,141)$ \\
\hline Free cash flow & $(\$ 19,595)$ & $\$ 189$ & $(\$ 19,661)$ & $(\$ 24,997)$ \\
\hline \hline
\end{tabular}

Look at these discouraging cash flow numbers and consider the following question: What is your forecast ... how long can General Motors survive with this "free" cash flow pattern? Well, no company can survive very long while burning $\$ 20$ billion of cash each year.

Given the General Motors "free" cash flow numbers we see from 2005 through 2008, we are not at all surprised to learn that this company declared bankruptcy in the very next year, in July 2009. Information from the statement of cash flows provides a very nice summary of a company's overall performance.

And how has General Motors done after its post-bankruptcy restructuring? Well, we can quickly answer that question just by looking at the same cash flow numbers for the restructured company.

\begin{tabular}{|l|r|r|r|r|r|}
\hline The Recovery: 2010-2014 & & & & \\
\hline (millions of U.S. dollars) & 2014 & 2013 & 2012 & 2011 & 2010 \\
\cline { 2 - 7 } Operating cash flow & $\$ 10,058$ & $\$ 12,630$ & $\$ 10,605$ & $\$ 8,166$ & $\$ 6,780$ \\
\hline Capital expenditures & $(7,091)$ & $(7,565)$ & $(8,068)$ & $(6,249)$ & $(4,202)$ \\
\hline Free cash flow & $\$ 2,967$ & $\$ 5,065$ & $\$ 2,537$ & $\$ 1,917$ & $\$ 2,578$ \\
\hline
\end{tabular}

Not bad. General Motors has had positive operating cash flow and positive free cash flow in each post-bankruptcy year. General Motors is back! The company is a cash cow!

This General Motors example illustrates the incredible amount that you can learn with a straightforward analysis of free cash flow. Information from the statement of cash flows provides a very nice summary of a company's overall performance.

\section{The Home Depot Story Revisited}

When last we considered Home Depot, back in 1985, cash flow problems had pushed the company to the wall. In fact, with a "cash burn rate" of $\$ 3$ million per week, and with just $\$ 9$ million cash in the bank, Home Depot had just three weeks to figure how to either get some additional external financing or reduce, dramatically, its "cash burn rate."

So, what did they do? A combination of factors, really. But much of what they did was focused on improving their operating cash flow. First and foremost, they launched an inventory management system that allowed them to track their inventory more carefully. With more careful inventory management, they didn't need as much inventory lying around idle in their warehouse stores. Less inventory lying around means fewer inventory purchases. And that means less cash flowing out to suppliers to pay for inventory that is just going to be sitting around on shelves. In 1985, Home Depot spent $\$ 69$ million to buy extra inventory. That contributed to their 1985 cash flow problems. In 1986, while still growing pretty rapidly, the company was able to keep that inventory increase down to $\$ 14$ million, saving their cash for other things. 
In 1986, Home Depot was also pro-active in collecting its outstanding receivables. Receivables are a potential source of cash, and Home Depot certainly needed cash. Home Depot was able to cut, in one year, its operating cycle (days' sales in inventory + average collection period) from 122 days down to 75 days. Home Depot also reduced its overhead expenses, increased its profit margins, and gently stretched out the time it took to pay its suppliers. All of these actions improved the company's operating cash flow and reduced the "cash burn rate."

Home Depot conducted an old-fashioned, roll-up-the-sleeves, back-to-basics restructuring of its operations. And it worked!! In fact, with these operating cash flow improvements, along with some interesting sale-leaseback transactions (a story for another day), Home Depot was able to completely turn around its cash flow position. From a "cash burn rate" of $\$ 3$ million per week in 1985, Home Depot switched over to a cash generation rate of almost $\$ 1$ million per week in 1986. An amazing turnaround.

It was this cash flow turnaround that rescued Home Depot and launched the company on its path to becoming the \#28 company in the Fortune 500 listing in 2016. And how about the company's cash "burn/generation" rate now? In 2015, Home Depot generated average surplus cash flow from operations, over and above the cash needed for capital expenditures, of \$150 million A WEEK (Home Depot 2016)!

Managers and owners of a company that is burning cash, such as Home Depot in 1985, spend much of their time worrying about survival. Managers and owners of a company that is generating cash, such as Home Depot in 2015, are free to spend their time thinking about new products and about long-term strategy. In short, a company's cash flow condition determines whether managers are forced to focus on a series of short term crises or are free to plan for the long-term future.

\section{Conclusion}

We have a friend who is a small business owner. Let's talk about his cash flow management practices. We will disguise the actual nature of his business, to preserve his privacy. He operates, let's say, a beach-side shop in a vacation beach area. He sells food, souvenirs, and some groceries. He also rents jet skis and scooters. His business is very seasonal ... high business in the late spring and summer and almost no business in the winter.

Our friend tells us that he maintains a rolling 30-day cash flow projection. He asks his financial staff to forecast how much cash the business will collect from customers and how much cash he will have to pay suppliers for each day for the next 30 days.

A few years ago, a big business shock threatened the survival of our friend's business. It was rumored that one of the big cruise lines would begin using his harbor as a stopping point. Of course, this would drastically increase customer traffic. Almost overnight, many new competitors materialized and moved onto our friend's beach. Our friend told us that new business owners came in, built or rented large store locations, filled them up with inventory, and purchased large collections of scooters and jet skis. A LOT of money was invested in the area.

Well, the rumors turned out to be false. No cruise lines came to the harbor. You can imagine the problems that hit these new competitors. Without sizeable cash inflow from the cruise line passengers, these new competitors were not able to maintain their cash payments for rent, inventory, wages, and so forth.

So, how did our friend do? He did great! Throughout the excitement, he just calmly proceeded with his normal business practice of constantly balancing his expected cash collections and expected cash payments for the next 30 days. Because he carefully monitored his cash flow, he was able to safely ride out the bubble and the subsequent crash. After the crash, he actually made quite a bit of money ... buying up the scooters and store inventory from his bankrupt competitors, the competitors who had not carefully planned and balanced their cash flows.

Cash flow management. Remember, many good businesses have died a premature death because they didn't properly manage their cash flow.

So, what should you do with respect to cash flow in your organization? Identify the operating, investing, and financing cash flows in your organization. Spend some time thinking about your operations and the time lags involved with collecting cash and paying your bills. Again, remember that many good businesses have died a premature death because they didn't properly manage their cash flow. You don't want your business to be one of those business. Watch your cash flow! 


\section{References}

Apple Inc. (2014). Financial Statements for Year Ended September 27, 2014. Filed with the Securities and Exchange Commission (SEC) October 27, 2014.

(2015). Financial Statements for Year Ended September 26, 2015. Filed with the Securities and Exchange Commission (SEC) October 28, 2015.

Boeing Company. (2013). from http://boeing.mediaroom.com/2013-11-17-Boeing-flydubai-Announce-Historic-Single-Aisle-Agreement

Central Intelligence Agency (CIA). (2013). The World Factbook 2013-14. Washington, DC.

Exxon Mobil Corporation. (2009). Financial Statements for Year Ended December 31, 2009. Filed with the Securities and Exchange Commission (SEC) February 27, 2009.

Financial Accounting Standards Board (FASB). (1987). Statement of Cash Flows. Statement of Financial Accounting Standards No. 95.

Fortune 500. (2016). Fortune. Retrieved from http://beta.fortune.com/fortune500/list

General Motors Company. (1998-2014). Financial Statements filed with the Securities and Exchange Commission (SEC).

Home Depot. (2016). Financial Statements for Year Ended January 31, 2016. Filed with the Securities and Exchange Commission (SEC) March 24, 2016.

International Accounting Standards Board (IASB). (1992). Cash Flow Statements. International Accounting Standard No.7.

McDonalds Corporation. (2016). Financial Statements for Year Ended December 31, 2015. Filed with the Securities and Exchange Commission (SEC) February 25, 2016.

Nike, Inc. (2015). Financial Statements for Year Ended May 31, 2015. Filed with the Securities and Exchange Commission (SEC) July 23, 2015.

Palepu, Krishna G. (1988). Home Depot, Inc., The. Harvard Business School Case 188-148, April 1988. (Revised October 1996).

\section{Notes}

Note 1. The cash flow statement used in the United Kingdom includes additional categories beyond these three. According to U.K. Financial Reporting Standard (FRS) 1, separate cash flow categories exist for both cash flows related to taxation and cash flows related to the payment and receipt of interest.

Note 2. These calculations reflect the operating practices of the 6,444 company-operated stores which represent $18 \%$ of the total number of 36,525 McDonalds restaurants, both company-operated and franchised.

Note 3. For years before 2009, General Motors financial statement data are found in the Securities and Exchange Commission (SEC) EDGAR database under the name "Motors Liquidation Company." 